\title{
THE INFLUENCE OF DIET ON GASTROINTESTINAL CANDID $A$ SPP. COLONIZATION AND THE SUSCEPTIBILITY OF CANDIDA SPP. TO ANTIFUNGAL DRUGS
}

\author{
Małgorzata Jeziorek ${ }^{1}$, Magdalena Frej-Mądrzak², Irena Choroszy-Król²
}

${ }^{1}$ Department of Dietetics, Faculty of Health Sciences, Wroclaw Medical University, Poland ${ }^{2}$ Department of Basic Sciences, Faculty of Health Sciences, Wroclaw Medical University, Poland

\begin{abstract}
Background. Candida spp. has been identified as the most common member of human gut microbiota. This yeast-like fungus is recognized as an opportunistic organism due to its potential to cause diseases in all parts of the gastrointestinal tract.

Objective. The aim of the study was to investigate the relationship between diet and health of the study participants and the presence of gastrointestinal Candida spp. Susceptibility of Candida to antifungal drugs was determined.

Material and methods. Material comprised of oral swabs and fecal samples self-collected by the study participants. The participants filled in a nutritional questionnaire. A total of 30 people took part in the study, including 28 women and 2 men. The study was conducted in Wroclaw, Poland. Susceptibility of Candida to antifungal drugs was determined using BioRad's FUNGITEST TM Kit designed for the susceptibility testing of yeasts to six antifungal drugs.

Results. In the group with negative Candida spp. cultures, healthier wheat flour substitutes were consumed significantly more frequently than in the group with positive Candida spp. cultures. Yellow cheeses and quark were eaten significantly more frequently in the group with negative Candida spp. cultures. No antifungal resistance was detected in the study group. Conclusions. The increased consumption of purified wheat flour products was linked to the presence of gastrointestinal Candida spp. A higher consumption of cheese was observed in the group with negative Candida spp. cultures, which may indicate the inhibitory effect of saturated fatty acids on the growth of human Candida spp. Sensitivity of C. albicans to antifungal drugs may increase effectiveness of candidiasis treatment.
\end{abstract}

Key words: Candida spp., diet, fecal samples, antibiotics, drug resistance

\section{STRESZCZENIE}

Wprowadzenie. Candida spp. to najczęstszy element mikroflory przewodu pokarmowego. Ten grzyb drożdżopodobny jest oportunistą, ze względu na możliwość powodowania chorób we wszystkich odcinkach przewodu pokarmowego. Pomimo, że Candi$d a$ spp. jest jedną z głównych przyczyn zakażeń oportunistycznych, to istnieje ograniczona liczba środków przeciwgrzybiczych stosowanych w terapii. Szerokie zastosowanie antybiotyków spowodowało zwiększenie oporności szczepów na stosowane leki. Cel. Celem pracy było zbadanie zależności między dietą i stanem zdrowia osób biorących udział w badaniu, a obecnością Candida spp. w przewodzie pokarmowym. Ponadto oceniono wrażliwość wyizolowanych szczepów Candida spp. na najczęściej stosowane leki przeciwgrzybicze.

Materiał i metody. Materiałem do badania były wymazy z jamy ustnej i próbki kału, pobrane samodzielnie przez badanych. Badani wypełniali ankietę dotyczącą częstotliwości spożycia różnych grup produktów spożywczych oraz występowania czynników ryzyka kandydozy. Przebadano 30 osób, w tym 28 kobiet i 2 mężczyzn. Badanie przeprowadzono na terenie miasta Wrocław, w Polsce. Oznaczono wrażliwości uzyskanych Candida na leki przeciwgrzybicze z użyciem zestawu FUNGITEST firmy Biorad, który umożliwia badanie wzrostu drożdżaków w obecności 6 preparatów przeciwgrzybiczych. Wyniki. Wykazano dodatnią korelację pomiędzy spożyciem produktów z oczyszczonej mąki pszennej, a występowaniem Candida spp. w przewodzie pokarmowym. Zaobserwowano wyższe spożycie serów w grupie osób z wynikiem ujemnym badania w kierunku Candida spp., co może wskazywać hamujący wpływ nasyconych kwasów tłuszczowych na wzrost Candida spp. w organizmie. Wśród badanych szczepów nie wykryto opornych na leki przeciwgrzybicze.

Wnioski. Duże spożycie produktów z pszennej, oczyszczonej mąki było związane z obecnością Candida spp. w przewodzie pokarmowym badanych. Konsumpcja produktów bogatych w nasycone kwasy tłuszczowe korelowała ze zmniejszoną liczebnością drożdżaków w przewodzie pokarmowym. Candida albicans wykazywał wrażliwość na wszystkie leki zastosowanie w teście, co może zwiększać skuteczność terapii kandydozy.

Słowa kluczowe: Candida spp., dieta, próbki kału, antybiotyki, lekooporność

Corresponding author: Małgorzata Jeziorek, Department of Dietetics, Faculty of Health Sciences, Wroclaw Medical University, Parkowa 34, 51-616 Wroclaw, Poland, Tel. +48 515746 698, e-mail: malgorzata.jeziorek@umed.wroc.pl

(C) Copyright by the National Institute of Public Health - National Institute of Hygiene 


\section{INTRODUCTION}

Candidaspp. is the most common member of human gut microbiota and estimated to be present in $40-60 \%$ of the general population $[1,2,14]$. It may be present as transient or permanent colonizer in the oral cavity and in the further parts of the gastrointestinal tract. This yeast-like fungus is considered an opportunistic microorganism capable of causing diseases in all parts of the gastrointestinal tract. The most important risk factors associated with Candida spp. infections include frequent use of antibiotics, chronic use of alcohol and immunosuppressive drugs, and high-carbohydrate diet $[2,14]$. The increased incidence of fungal infections contributes to higher morbidity and mortality rates. This is due to increased antimicrobial resistance and a limited number of antifungal drugs that have many side effects. Candida spp. can cause infections of mucous membranes and deep tissues $[6,8,11]$.

Although Candida spp. strains are mainly responsible for opportunistic fungal infections, they have acquired complex and multifaceted resistance to antifungal treatment. It may be induced in reaction to a compound or due to a genetic mutation resulting from prolonged drug exposure [11]. The rapidly increasing resistance of fungal pathogens to commonly used antifungal drugs is becoming a challenge for modern medicine. Increased drug-resistance is associated with the widespread use of antibiotics. The emergence of resistant strains have contributed to the increased mortality and therefore prompted search for novel antifungals. A thorough drug resistance control should be carried out in the case of treating Candida strains exhibiting reduced susceptibility to antifungals $[4,10,13]$.

The aim of the study was to demonstrate the relationship between diet and the presence of risk factors associated with the growth of human Candida spp. The study was based on the analysis of oral swabs and fecal samples for the presence of Candida spp. The results obtained allowed us to indicate the correlation between particular elements of diet and the presence of Candida spp.

\section{MATERIAL AND METHODS}

Material consisted of oral swabs and fecal samples self-collected by the study participants who had been instructed about the appropriate method for sample collection and storage. Respondents filled in the questionnaire on the frequency of consumption of selected food groups, used drugs, diseases and infections, and the degree of physical activity. The investigation was performer in accordance with the Declaration of Helsinki for Human Research. The research was carried out from statutory founds of Wroclaw Medical University No. ST.E090.18.021.
A total of 30 people were examined, including 28 women and 2 men. The study was conducted in Wroclaw (Poland) from April to May 2017. The mean age of the study group was $23.8 \pm 1.98$ years.

The material (feces and oral swabs) was cultured on Sabouraud dextrose agar with actidione (cycloheximide) by GRASO. The significant growth of Candida spp. on Sabouraud's medium in the form of white, oval colonies with a characteristic yeast smell was evaluated as a positive result. Then, for selective isolation of yeast, the material was cultured on the chromogenic substrate. The identification of individual species was carried out according to the color of colony growth. Candida spp. colonies were classified according to the guidelines of the manufacturer (GRASO Biotech). Candida albicans developed green colonies, Candida krusei pink, and Candida glabrata light purple. Collected samples underwent Gram's staining. Large oval cells arranged in clusters and/or individually indicated the presence of Candida spp. The susceptibility of Candida to antifungal drugs was determined using the Bio-Rad's FUNGITEST TM Kit, which allows the susceptibility testing of yeasts to six antifungal agents at two different concentrations. The presence of a redox indicator allowed a colorimetric reading. The test included 5-fluorocytosine, amphotericin B, miconazole, ketoconazole, itraconazole and fluconazole.

\section{RESULTS}

The study involved 30 people, including 28 women and 2 men. Fecal samples and oral swabs were collected from the participants of the study. Isolates were cultured on Sabouraud's medium. Thirteen strains were obtained after incubation, most were identified as Candida albicans, but we also identified Candida glabrata and Candida krusei (Table 1). All strains demonstrated morphology typical for Candida species, and were differentiated on the CHROMagar Candida Medium.

Table 1. Type of strains in the group with positive Candida spp. cultures

\begin{tabular}{|l|c|}
\hline \multicolumn{1}{|c|}{ Isolates } & $\%(\mathrm{n}=13)$ \\
\hline Candida albicans & 84.6 \\
\hline Candida glabrata & 7.7 \\
\hline Candida krusei & 7.7 \\
\hline
\end{tabular}

In Candida spp. positive group, the yeast was reported in the oral cavity, feces and both (the oral cavity and feces). Candida glabrata strains were isolated only from feces and Candida krusei strains from the oral cavity and feces. We reported a low growth of Candida spp. cultures in over $50 \%$ of isolates. A significant growth (assessed at 3+) of Candida spp. cultures from the oral cavity occurred in two people (Table 2). 
Table 2. Characteristic of isolates

\begin{tabular}{|l|c|c|c|c|}
\hline Isolation & $\begin{array}{c}(\mathrm{n}=30) \\
\%\end{array}$ & $\begin{array}{c}\text { Significant growth (3+) } \\
\%\end{array}$ & $\begin{array}{c}\text { Moderate growth (2+) } \\
\%\end{array}$ & $\begin{array}{c}\text { Low growth (1+) } \\
\%\end{array}$ \\
\hline Total & 43.3 & 15.4 & 30.8 & 53.8 \\
\hline Oral cavity & 38.5 & 100.0 & 25.0 & 42.9 \\
\hline Feces & 38.5 & 0 & 50.0 & 42.9 \\
\hline Oral cavity and feces & 23.1 & 0 & 25.0 & 14.2 \\
\hline
\end{tabular}

Respondents filled in questionnaires that included information on their lifestyle and diet. The questionnaire asked about the use of antibiotics, pregnancy, susceptibility to infections, and previous fungal infections or surgeries. There was no correlation between the incidence of Candida spp. risk factors in the study group and the presence of yeasts in the Candida spp. positive group.

In the group with positive Candida spp. cultures, the majority of respondents declared symptoms such as abdominal pain, flatulence and unrestrained appetite for sweets. The minority of respondents declared restless sleep, nausea and a metallic taste in the mouth. One person did not experience any symptoms listed in the questionnaire (Table 3).

Table 3. Frequency of symptoms in the group with positive Candida spp. cultures

\begin{tabular}{|l|c|}
\hline \multicolumn{1}{|c|}{ Symptoms } & $\%$ \\
\hline Abdominal pain & 69.2 \\
\hline Flatulence & 53.8 \\
\hline Unrestrained appetite for sweets & 53.8 \\
\hline Restless sleep & 15.4 \\
\hline Nausea & 15.4 \\
\hline Metallic taste in the mouth & 15.4 \\
\hline Not experienced any symptoms & 7.7 \\
\hline
\end{tabular}

Respondents were asked about their diet taking into account particular groups of food products and the frequency of their consumption.
Most of respondents did not follow any elimination diet. Respondents could choose several variants of their diets. The most frequently mentioned diets were milk-free, lactose-free and gluten-free. Among the respondents from the group with positive Candida spp. cultures, the majority of them had not followed any elimination diet.

In the group with positive Candida spp. cultures, more than half declared they ate white and wholegrain flour. In the group with negative Candida spp. cultures, healthier wheat flour substitutes were consumed significantly more frequently $(\mathrm{p}=0.04)$ than in the group with positive Candida spp. cultures.

Over $50 \%$ of respondents consumed natural white quark regularly. Average consumption of yellow cheese (eg. Gouda) was comparable in the group with positive and negative Candida spp. cultures. Quark were eaten significantly more frequently $(\mathrm{p}=0.005)$ in the group with negative Candida spp. cultures.

The majority of respondents admitted using different types of vegetable oils to prepare both heated and cold food. Most frequently used were vegetable oils including olive oil. In the group with positive Candida spp. cultures, the majority of respondents used vegetable oils, the minority of respondents chose butter. In the group with negative Candida spp. cultures the results were comparable.

Frequency of consumption particular groups of food products was presented in Table 4.

Table 4. Description of population surveyed diet

\begin{tabular}{|c|c|c|c|}
\hline Specification & $\begin{array}{l}\% \text { (the whole } \\
\text { group, } n=30)\end{array}$ & $\begin{array}{l}\% \text { (the group with positive } \\
\text { Candida spp. cultures, } \mathrm{n}=13 \text { ) }\end{array}$ & $\begin{array}{l}\% \text { (the group with negative } \\
\text { Candida } \text { spp. cultures, } \mathrm{n}=17 \text { ) }\end{array}$ \\
\hline \multicolumn{4}{|c|}{ Elimination diet } \\
\hline Milk-free & 10.0 & 15.4 & 5.9 \\
\hline Lactose-free & 10.0 & 7.7 & 11.8 \\
\hline Gluten-free & 13.0 & 7.7 & 17.6 \\
\hline Not followed any diet & 76.7 & 76.9 & 76.5 \\
\hline \multicolumn{4}{|c|}{ Frequency of consumption particular groups of food products } \\
\hline Wheat flour & 23.3 & 15.4 & 29.4 \\
\hline Wholegrain flour & 33.3 & 15.4 & $47.1(\mathrm{p}=0.04)$ \\
\hline White and wholegrain flour & 43.3 & 69.2 & 23.5 \\
\hline Natural white quark & 66.7 & 53.9 & $76.5(\mathrm{p}=0.005)$ \\
\hline Yellow cheese & 39.9 & 38.5 & 41.2 \\
\hline Vegetable oils & 70.0 & 69.2 & 70.6 \\
\hline Olive oil & 20.0 & 23.1 & 17.6 \\
\hline Coconut oil & 3.3 & 0 & 5.9 \\
\hline Butter & 3.3 & 7.7 & 0 \\
\hline Clarified butter & 3.3 & 0 & 5.9 \\
\hline
\end{tabular}


The study included 16 Candida spp. isolates cultured on Sabouraud medium, including isolates from feces and from the oral cavity. Almost 100\% isolates were susceptible to 5-fluorocytosine, amphotericin B,

Table 5. Susceptibility of Candida spp. to antifungal drugs

\begin{tabular}{|c|c|c|c|c|c|c|c|c|}
\hline \multirow{2}{*}{ Strains } & \multirow{2}{*}{$\begin{array}{c}\text { Isolates } \\
\text { from oral } \\
\text { cavity (\%) }\end{array}$} & \multirow{2}{*}{$\begin{array}{c}\text { Isolates } \\
\text { from feces } \\
(\%)\end{array}$} & \multicolumn{6}{|c|}{$\begin{array}{c}\text { Susceptible strains } \\
(\%)\end{array}$} \\
\hline & & & $\begin{array}{l}\text { 5-fluoro- } \\
\text { cytosine }\end{array}$ & Amphotericin B & Miconazole & Ketoconazole & Itraconazole & Fluko-nazole \\
\hline $\begin{array}{l}\text { Candida } \\
\text { albicans }\end{array}$ & $\begin{array}{c}37.5 \\
- \\
6.3\end{array}$ & $\begin{array}{l}12.5 \\
12.5 \\
12.5\end{array}$ & $\begin{array}{c}100.0 \\
100.0 \\
\text { moderate }\end{array}$ & $\begin{array}{c}100.0 \\
100.0 \\
\text { moderate }\end{array}$ & $\begin{array}{c}100.0 \\
100.0 \\
\text { moderate }\end{array}$ & $\begin{array}{c}100.0 \\
100.0 \\
\text { moderate }\end{array}$ & $\begin{array}{c}100.0 \\
\text { moderate } \\
\text { moderate }\end{array}$ & $\begin{array}{c}100.0 \\
100.0 \\
\text { moderate }\end{array}$ \\
\hline $\begin{array}{l}\text { Candida } \\
\text { glabrata }\end{array}$ & - & 6.3 & 100.0 & 100.0 & 100.0 & 100.0 & moderate & 100.0 \\
\hline $\begin{array}{l}\text { Candida } \\
\text { krusei }\end{array}$ & 6.3 & 6.3 & 100.0 & 100.0 & 100.0 & 100.0 & 100.0 & 100.0 \\
\hline
\end{tabular}

\section{DISCUSSION}

Diet significantly influences the composition and activity of intestinal microbiota, including fungi. High-fat and high-carbohydrate diets are of particular importance. Specific nutrients change the microbial composition and metabolic activity of the physiological flora [5]. Carbohydrates, proteins and individual fatty acids are most frequently studied compounds that influence the growth of Candida in the gastrointestinal tract. Scientific research proves that diet contributes to the growth of human Candida spp. [7]. Carbohydrates lead to the highest rated of Candida spp. growth in the digestive tract, whereas yeast growth is inhibited by saturated fatty acids $[6,7]$. It has been reported that probiotics and flavonoids inhibit Candida spp. growth $[9,12]$.

The influence of diet on the development of Candida spp. has been proved by examining fecal samples taken from healthy adults as well as by analyzing their current diets. Hoffmann et al. [7] in 2013 reported a positive correlation between the presence of Candida spp. in the human gastrointestinal tract, high carbohydrate intake and a negative correlation between the presence of Candida spp. and saturated fatty acids intake. The study described the metabolic activity of Candida spp., which is capable of fermenting starch, especially after preliminary amylase digestion in saliva. Therefore, yeast may participate in the decomposition of starch from high carbohydrate products and contribute to the release of simple sugars which are a fermentation substrate for this type of fungus.

In this research the authors reported differences in the consumption of high carbohydrate foods between our respondents. People with positive Candida spp. cultures more frequently consumed cereal from purified than from whole-grain flour. The diet of people with negative Candida spp. cultures more often included healthier wheat flour substitutes (e.g. rye flour, oat flour, buckwheat flour). Potatoes, which miconazole, ketoconazole, itraconazole, and fluconazole. A few isolates showed moderate susceptibility mainly to itraconazole. Candida albicans was the most susceptible to antifungal drugs. No antifungal resistance was detected in the study group (Table 5).

are a rich source of starch, were more frequently found in the diet of people with Candida spp. There were no differences in the frequency of consumption and the type of sweets among the respondents of this study.

Gunsalus et al. [6] evaluated the effect of different types of food fats on gastrointestinal tract infestation by $C$. albicans and compared the role of beef tallow, soybean and coconut oils in the process of $C$. albicans multiplication in the intestines of mice. Beef tallow and soybean oil are rich in long-chain saturated fatty (C16:0 and $\mathrm{C} 18: 0)$ and unsaturated fatty acids (C18:1 and $\mathrm{C} 18: 2$ ). Coconut oil is rich in medium- and short-chain fatty acids. Coconut oil used in in vitro conditions inhibited the growth of C. albicans and led to the death of strains. This effect was mainly attributed to short-chain fatty acids such as capric (C10:0) and lauric acids (C12:0). On the other hand, long-chain fatty acids contained in soybean oil and beef tallow enhanced the growth of $C$. albicans. The colonization with $C$. albicans was lower in mice fed with coconut oil than in mice fed with beef tallow or soybean oil. The researchers concluded that coconut oil inhibits C. albicans growth under in vivo conditions.

In this study, the highest percentage of respondents with positive Candida spp. cultures (69.2\%) used vegetable oils (such as rapeseed oil or sunflower oil), whereas only 1 person used fat containing short chain fatty acids, such as coconut oil or butter. Comparable results were obtained in the group with negative Candida spp., therefore it can be concluded that in the studied material the type of chosen fat had no significant effect on the presence of gastrointestinal Candida spp. After analyzing the consumption of products containing a large amount of saturated fatty acids, authors of this research reported that people with negative Candida spp. cultures consumed significantly more yellow cheese and quark, which are the source of short-chain fatty acids. 
Due to the increasing drug resistance of yeastlike fungi to fungistatic drugs, there have been many reports on the effectiveness of antifungal treatment. Researchers from the Department of Periodontology and Oral Mucosa Diseases at the Medical University of Gdansk (Poland) examined the antifungal resistance profile of isolated yeast-like strains in 197 patients. For this purpose, they used oral isolates obtained from the participants of the study and treated them with 7 fungistatic drugs (nystatin, amphotericin B, fluconazole, miconazole, ketoconazole, itraconazole and flucytosine). The most frequently isolated Candida albicans strains (70.4\%) showed the highest susceptibility to all antifungals tested. The highest percentage $(93.0 \%)$ of C. albicans strains was susceptible to amphotericin B and nystatin (91.7\%). The highest resistance to antifungal agents was observed among Candida krusei (2.7\%) and Candida glabrata $(9.9 \%)$ strains. C. krusei showed 100\% resistance to fluconazole and itraconazole. C. glabrata strains were most resistant to fluconazole (95.5\%). Amphotericin B and nystatin were characterized by the highest probability of clinical efficacy for all isolated yeast-like fungi. Susceptibility to amphotericin was demonstrated in $92.9 \%$ of C. albicans, $81.8 \%$ of C. glabrata, and $100 \%$ of C. krusei. In the case of nystatin, the percentage of susceptible strains was lower and for C. albicans, C. glabrata and C. krusei amounted to $91.7 \%, 77.3 \%$, and $66.7 \%$, respectively. Azole derivatives were assessed as less effective than amphotericin B and nystatin. $68.3 \%$ of C. albicans and $13.6 \%$ of C. glabrata strains showed susceptibility to azole antifungal drugs, whereas C. krusei isolates were resistant to all azole drugs tested [3]. Similarly in this study, C. albicans strains were most susceptible to the majority of antifungal drugs. $61.5 \%$ of strains were susceptible to 5-fluorocytosine, amphotericin B, miconazole, ketoconazole, itraconazole, and fluconazole. $15.4 \%$ showed susceptibility to 5 drugs and moderate susceptibility to itraconazole. $23.1 \%$ of isolates were moderately susceptible to all the drugs tested. C. glabrata isolates were susceptible to all drugs tested except for itraconazole, for which they showed moderate susceptibility. C. krusei strains were susceptible to all drugs used in the test.

\section{CONCLUSION}

Results of statistical analysis suggests a positive correlation between the consumption of high carbohydrate content foods (such as products made from wheat flour) and the presence of gastrointestinal Candida spp. and a negative correlation between the presence of gastrointestinal Candida spp. and the consumption of products rich in saturated fatty acids.
Use the Bio-Rad's FUNGITEST ${ }^{\text {TM }}$ Kit which allows the susceptibility testing of yeasts to six antifungal agents at two different concentrations determines Candida albicans strains are most commonly susceptible to antifungal drugs.

\section{Conflict of interest}

The Authors declare no conflict of interest.

\section{REFERENCES}

1. Angebault C., Djossou F., Abélanet S., Permal E., Soltana M.B., Diancourt L., Bouchier C., Woerther P.L., Catzeflis F., Andremont A., d'Enfert C., Bougnoux M.E. Candida albicans is not always the preferential yeast colonizing humans: a study in Wayampi Amerindians. J Infect Dis. 2013;208(10): 1705-1716, doi: 10.1093/ infdis/jit389.

2. Arzmi M.H., Alshwaimi E. ,Wan Harun W.H.A.,Razak F.A., Farina F., McCullough M.J., Cirillo N.: Gaining more insight into the determinants of Candida species, pathogenicityintheoralcavity.EurJInflamm.2014;12(2): 227-235, doi: 10.1177/1721727X1401200202

3. Bochniak M., Kusiak A.: Assessment of the clinical effectiveness probability for the empiric therapy of oral fungal infections. Dent Forum. 2017;45(1): 11-20: (in Polish).

4. BondarykM., Kurzatkowski W., Staniszewska M.: Ocena prawdopodobieństwa klinicznej skuteczności terapii empirycznej zakażeń grzybiczych błony śluzowej jamy ustnej. [Antifungal agents commonly used in the superficial and mucosal candidiasis treatment: mode of action and resistance development] Postep Derm Alergol. 2013;30(5):293-301, doi:10.5114/ pdia.2013.38358.

5. David L.A., Maurice C.F., Carmody R.N., Gootenberg D.B., Button J.E., Wolfie B.E., Ling A.V., Devlin A.S., Varma Y., Fischbach M.A., Biddinger S.B., Dutton R.J., Turnbaugh P.J.: Diet rapidly and reproducibly alters the human gut microbiome. Nature 2014;505:559-563, doi:10.1038/nature12820.

6. Gunsalus K.T.W., Tornberg-Belanger S.N., Matthan N.R., Lichtenstein A.H., Kumamoto C.A.: Manipulation of host diet to reduce gastrointestinal colonization by the opportunistic pathogen Candida albicans. Host Microbe Biology. 2015;1(1): 1-16, doi:10.1128/ mSphere.00020-15.

7. Hoffmann C., Dollive S., Grunberg S., Chen J., Li H., Wu G.D., Lewis J.D., Bushman F.D.: Archaea and fungi of the human gut microbiome: correlations with diet and bacterial residents. Plos One, 2013, 8(6):1-12, doi:10.1371/journal.pone.0066019.

8. Koh A.Y: Murine models of candida gastrointestinal colonization and dissemination. Eukaryot Cell, 2013;12(11): 1416-1422, doi:10.1128/EC.00196-13.

9. Kumar S., Singhi S.: Role of probiotics in prevention of Candida colonization and invasive candidiasis. J Matern Fetal Neo M. 2016,;29(5): 818-819, doi:10.31 09/14767058.2015.1009032. 
10. Rodrigues C. F., Silva S. Henriques M.: Candida glabrata: a review of its features and resistance. Eur J Clin Microbiol Infect Dis. 2014;33(5): 673-688, doi:10.1007/s10096-013-2009-3.

11. Sardi J.C.O., Scorzoni L., Bernardi T., Fusco-Almeida A.M., Mendes Giannini M.J.S.: Candida species: current epidemiology, pathogenicity, biofilm formation, natural antifungal products and new therapeutic options. J Med Microbiol. 2013, 62: 10-24, doi:10.1099/ jmm.0.045054-0.

12. Seleem D., Pardi V., Murata R.M.: Review of flavonoids: a diverse group of natural compounds with anti-Candida albicans activity in vitro. Arch Oral Biol. 2017;76:76-83, doi:10.1016/j.archoralbio.2016.08.030.
13. Staniszewska M., Bondaryk M., Kowalska M., Magda U., Łuka M., Ochal Z., Kurzątkowski W.: Patogeneza i leczenie zakażeń Candida spp, [Pathogenesis and treatment of fungal infections by Candida spp.]. Post Mikrobiol. 2014;53(3): 229-240: (in Polish).

14. Valentijn-Benz M., Nazmi K., Brand H.S., van't Hof W., Veerman E.C.I.: Growth of candida albicans in human saliva is supported by low-molecular-mass compounds FEMS Yeast Res. 2015;15(8): 1-8, doi:10.1093/femsyr/ fov088.

Received: 08.03.2019

Accepted: 30.04.2019 